\title{
Carbon Dioxide Emissions and Spatial Variability Affected by Drip Irrigation Methods in a Pomegranate Orchard
}

\author{
Suduan Gao, Aileen Hendratna, Zejiang Cai, Tom Pflaum, Ruijun Qin, and Claude Phene
}

\begin{abstract}
Mitigation of greenhouse gas emissions is essential to combat climate change, and also for sustainable agriculture. Agriculture is facing a growing number of challenges including water shortage and environmental degradation that threaten crop production. In this research, field monitoring was carried out to evaluate the effects of drip irrigation methods and nitrogen (N) fertilization level on carbon dioxide $\left(\mathrm{CO}_{2}\right)$ emissions in a 5-year old pomegranate orchard. Surface drip irrigation (DI) and subsurface drip irrigation (SDI) were tested as main treatments. Three $\mathrm{N}$ application rates $(50 \%, 100 \%$, and $150 \%$ in reference to current practices) were applied as sub-treatments. $\mathrm{CO}_{2}$ emission data were collected during the growing season. The $\mathrm{CO}_{2}$ flux near the irrigation line was significantly higher from DI (ave. $2.67 \mu \mathrm{mol} \mathrm{m} \mathrm{m}^{-2} \mathrm{~s}^{-1}$ ) than SDI (ave. $1.74 \mu \mathrm{mol} \mathrm{m}^{-2} \mathrm{~s}^{-1}$ ). There were significant spatial variations surrounding a tree from DI but much less from SDI. However, no significant differences in cumulative $\mathrm{CO}_{2}$ emissions were determined between DI (7.5-9.5 $\left.\mathrm{Mg} \mathrm{ha}^{-1}\right)$ and SDI (7.7-9.0 Mg $\mathrm{ha}^{-1}$ ) due to small wetting areas under DI. These values may subject to error due to the limited number of sampling times in spatial variations. The higher DOC and water content in surface soil from DI contributed to the higher $\mathrm{CO}_{2}$ emissions in comparison to SDI. The spatial variation should be considered to accurately estimate $\mathrm{CO}_{2}$ emissions in orchard settings especially with irrigation systems. The SDI provides overall benefits of water savings, improvement on nutrient use efficiency, and reduction in total greenhouse gas emissions.
\end{abstract}

Index Terms-Greenhouse gas emission, high-frequency drip irrigation, surface drip irrigation, subsurface drip irrigation, fertigation.

\section{INTRODUCTION}

Carbon dioxide $\left(\mathrm{CO}_{2}\right)$ accounts for $82 \%$ of the total greenhouse gas (GHG) emissions in the USA [1]. As the

Manuscript received February 12, 2020; revised March 19, 2020. This work was supported by the U.S. Depart $\neg$ ment of Agriculture, Agricultural Research Service Base Funds. Mention of trade names or commercial products in this publication is solely for the purpose of providing specific information and does not imply recommendation or endorsement by the U.S. Department of Agriculture. USDA is an equal opportunity provider and employer.

S. Gao, A. Hendratna, and T. Pflaum are with USDA, Agricultural Research Service, San Joaquin Valley Agricultural Sciences Center, Parlier, CA 93648, USA (e-mail: suduan.gao@ars.usda.gov, aileen.hendratna@ars.usda.gov, brasscuzn@aol.com).

Z. Cai is with Institute of Agricultural Resources and Regional Planning, Chinese Academy of Agricultural Sciences, Beijing 100081, China (e-mail: caizejiang@caas.cn).

R. Qin is with Hermiston Agricultural Research \& Extension Center, Oregon State University, Hermiston, OR 97838, USA (e-mail: ruijun.qin@oregonstate.edu).

C. J. Phene is with SDI+ Consultant, Clovis, CA 93613, USA (e-mail: claudejphene@gmail.com). second largest terrestrial carbon (C) flux, soils around the globe have increased $\mathrm{CO}_{2}$ emissions over the past few decades and are predicted to release more $\mathrm{CO}_{2}$ with the climate change by increasing microbial consumption of plant debris and organic matter [2]. Soil, however, can help combat and adapt to climate change because of its ability to store large amount of organic C (carbon sequestration) when managed with sustainable practices [3].

Agricultural activities can have a great impact on $\mathrm{CO}_{2}$ emissions because soils can serve as either a source or a sink [4], [5]. Conservation practices play important role in sequestering soil organic $\mathrm{C}$ such as manure amendment, residue incorporation, mulch, and increased cropping intensity that increase $\mathrm{C}$ input, and those practices slowing down decomposition of soil organic matter using no or reduced tillage [6]-[8]. Effective water and nutrient management also result in reduced $\mathrm{CO}_{2}$ emissions [9]-[11], but these studies are inconclusive regarding irrigation method or the amount of water or source of fertilizer [12]-[14]. Irrigation and fertilization were found to increase $\mathrm{CO}_{2}$ emissions [15]. Deficit irrigation was found with lower emissions [9], [10]. Subsurface watering was found to delay or have lower $\mathrm{CO}_{2}$ emission flux [16]. However, some research showed no significant soil moisture effects [17]. In saline/alkaline soils, inorganic $\mathrm{CO}_{2}$ diffusion and dissolution can contribute to reduced $\mathrm{CO}_{2}$ flux [18]. More field data are needed that evaluate multiple environmental factors and determine irrigation and nutrient management practices on $\mathrm{CO}_{2}$ emissions.

Soil respiration releases $\mathrm{CO}_{2}$ from microbial and plant activities [7]. Microbial respiration can account for up to $99 \%$ of soil $\mathrm{CO}_{2}$ emissions and root respiration can account for up to $50 \%$ [19]. Microbes decompose soil organic matter for their energy source and releases $\mathrm{CO}_{2}$ and nutrients. This process can be affected by many environmental factors (soil temperature and water content) [20] and practices influencing these factors such as tillage or irrigation that affect soil air porosity [21]. Water content is one of the most important factors affecting soil respiration, and different irrigation system would impact water distribution in soil. Drip irrigation, especially subsurface drip, can increase water use efficiency with other benefits [22], but its effect on $\mathrm{CO}_{2}$ emissions from irrigated field is not clear because of limited number of studies.

California (CA) is the most agricultural producing state in the United States with a total of $\$ 50.13$ billion (USD) output in 2017 [23]. San Joaquin Valley (SJV) (south part of the Central Valley of CA) is one of the most productive regions 
in the world with an annual agricultural output exceeding $\$ 30$ billion (USD). The SJV's climate is Mediterranean, i.e., with hot/dry summers and cool/moist winters and all crops rely on irrigation. However, water shortage has become more frequent forcing the region to seek more efficient irrigation technology and drought tolerant crops, such as pomegranate (Punica granatum L.).

To evaluate water and nitrogen $(\mathrm{N})$ requirement as well as their use efficiency affected by irrigation method and $\mathrm{N}$ application level, a field experiment was conducted from 2010-2015 in a pomegranate (var. Wonderful) orchard in the SJV. The field treatments included two irrigation methods as the main treatments: commonly used surface drip irrigation (DI) in the region and subsurface drip irrigation (SDI) and three $\mathrm{N}$ application rates as sub-treatments. Ayars et al. [22] reported the findings on treatment effects on yield, crop $\mathrm{N}$ requirement, and weeds. Tirado-Corbalá et al. [24] examined $\mathrm{C}$ and $\mathrm{N}$ dynamics from this field research. We also measured greenhouse gas nitrous oxide $\left(\mathrm{N}_{2} \mathrm{O}\right)$ emissions for two years and the results were reported in Gao et al. [25]. The previous studies have concluded that SDI led to water savings and much lower weed pressure in comparison with DI and there was significantly higher $\mathrm{N}$ uptake in fruits from SDI at least in two out of the last three years of measurements [22]. Although soil N concentration was higher in subsurface soil under SDI from fertigation, using high irrigation frequency can reduce leaching potential [24]. The SDI resulted in significantly lower $\mathrm{N}_{2} \mathrm{O}$ emissions than DI [25]. The objective of this paper was to evaluate the effects of drip irrigation method and $\mathrm{N}$ fertilization level on $\mathrm{CO}_{2}$ emissions during growing season and evaluate spatial variations. The data were collected when the pomegranate orchard entered its fifth year.

\section{MATERIALS AND METHODS}

\section{A. Study Site, Treatments, and Field Operation}

Carbon dioxide emissions were measured in 2014 in the 1.4 ha pomegranate orchard established in 2010 at the University of California, Kearney Agricultural Research and Extension Center, Parlier. CA, which is situated within the SJV, USA. The soil was Hanford sandy loam (coarse-loamy, mixed, superactive, nonacid, thermic Typic Xerorthents). The soil has $17 \%$ water content at $33 \mathrm{kPa}$ that can translate to a field capacity of $\sim 26 \%(\mathrm{v} / \mathrm{v})$ with an average bulk density of $1.55 \mathrm{~g} \mathrm{~cm}^{-3}$ [26]. Details on the project, soil property, and orchard operation can be found in Ayars et al. [22] and in Gao et al. [25]. All trees received the same amount of $\mathrm{N}$ fertilizers during the first two years to ensure uniform growth prior to different irrigation and fertilization treatments starting in 2012. The field used a split-plot design with two irrigation methods: DI and SDI as the main treatments, and three $\mathrm{N}$ application rates of 50,100 , and $150 \%$ of current practice as sub-treatments. Each treatment plot consisted of three tree rows with a total of seven trees in a row. Row spacing and tree spacing in a row was 4.9 and $3.6 \mathrm{~m}$, respectively. Carbon dioxide emissions were measured during growing/irrigation season of 2014 in three replications The middle row in each treatment plot was used for monitoring. Both DI and SDI included two irrigation drip laterals with one on each side at a distance $1.1 \mathrm{~m}$ from the tree on soil surface for DI or buried at soil depth of $50-55 \mathrm{~cm}$ for SDI. Irrigation was triggered after $1 \mathrm{~mm}$ of crop water use measured in a lysimeter located within the field, thus the system can reach irrigation frequency as high as 8-12 times per day during summer.

For the different levels of $\mathrm{N}$ fertilization treatments, N-pHURIC ${ }^{\circledR} 10 / 55$ (urea and sulfuric acid with $10 \% \mathrm{~N}$ and $18 \% \mathrm{~S}$ ) was injected through irrigation system to all N1, N2, and $\mathrm{N} 3$ treatments first, additional $\mathrm{N}$ requirement for $\mathrm{N} 2$ and N3 was injected with ammonium nitrate $(20 \% \mathrm{~N}$ or AN20), and all treatments received the same amount of $\mathrm{P}$ and $\mathrm{K}$ supply (Table I). Fertilizer application began in early May through September. Total $\mathrm{N}$ applied during the growing season was 54, 216 and $336 \mathrm{~kg} \mathrm{ha}^{-1}$ for $\mathrm{N} 1, \mathrm{~N} 2$, and N3 treatments, respectively.

TABLE I: FERTILIZATION RATES $\left(\mathrm{KG} \mathrm{HA}^{-1}\right.$ ) FOR THREE LEVELS OF N TREATMENTS DURING 2014 GROWING SEASON IN POMEGRANATE ORCHARD

\begin{tabular}{lccc}
\hline \multirow{2}{*}{ Fertilizers } & \multicolumn{3}{c}{ Treatments } \\
\cline { 2 - 4 } & $\mathrm{N} 1$ & $\mathrm{~N} 2$ & $\mathrm{~N} 3$ \\
\hline Nitrogen (N-pHURIC) & 54.3 & 54.3 & 54.3 \\
Nitrogen (AN-20) & 0 & 161.4 & 281.3 \\
Total N & 54.3 & 215.7 & 335.6 \\
Phosphorous $\left(\mathrm{H}_{3} \mathrm{PO} 4\right)$ & 88.8 & 88.8 & 88.8 \\
Potassium $\left(\mathrm{K}_{2} \mathrm{~S}_{2} \mathrm{O}_{3}\right)$ & 83.9 & 83.9 & 83.9 \\
\hline \hline
\end{tabular}

\section{B. Soil Temperature/Moisture Monitoring, DOC Measurement}

To demonstrate differences between the two irrigation systems, soil temperature and moisture was monitored for a week in May 2014. Soil temperature was measured using a HOBO® U12 Outdoor Datalogger (Onset Computer Corp., Bourne, MA, USA) with TMC20-HD air/water/soil temperature sensor. Soil moisture was monitored using a Decagon EM50 datalogger with Decagon Devices 10HS moisture sensor (METER Group, Inc., Pullman, WA, USA). Soil samples were collected at the end of growing season for dissolved organic carbon (DOC) analysis, which is better to correlate to soil respiration than other parameters. The analysis was done using a Teledyne Tekmar TOC Fusion Analyzer (Teledyne Tekmar, Mason, OH, USA) from soil extract. Soil was air-dried and sieved through $2 \mathrm{~mm}$. The extract was obtained after mixing $50 \mathrm{~g}$ soil with $50 \mathrm{~mL}$ deionized water, allowed to stand undisturbed for $24 \mathrm{~h}$, then shaken for $1 \mathrm{~h}$ on a reciprocating shaker, vacuum filtered through Whatman ${ }^{\circledR}$ no. 42 filter paper, diameter $90 \mathrm{~mm}$, and then followed with another vacuum filtration through Millipore $^{\mathrm{TM}} 0.45 \mu \mathrm{m}$ nitrocellulose membrane, diameter 47 $\mathrm{mm}$.

\section{C. $\mathrm{CO}_{2}$ Emission Measurements}

A LI-8100A automated $\mathrm{CO}_{2}$ flux system (model 8100-103, LI-COR ${ }^{\circledR}$ Biosciences, Lincoln, NE, USA) was used with a single $20 \mathrm{~cm}$ survey chamber to measure the emissions (Fig. 1). The system is automated, and designed to measure soil $\mathrm{CO}_{2}$ efflux at soil surface. Similar systems had been used by 
other researchers [27]-[29]. The system can be carried easily throughout the field. Details about the system can be found at https://www.licor.com/env/pdf/soil_flux/8100A_brochure.p df. A collar that is designed specifically for the chamber was inserted into the surface soil prior to measurement with $3 \mathrm{~cm}$ as chamber offset (distance between soil surface and top of the collar). The system was programed to make each measurement within 90 seconds upon chamber closure. Data could be processed for flux based on a linear or an exponential function. We chose the flux computed with the exponential function. The system also included a probe that is used to measure soil temperature and water content at 10-15 $\mathrm{cm}$ soil depth. Emission measurements were made twice per week from mid-May to mid-October. Data collection was made between 9:00-11:00 in the morning, which roughly represented average flux of the day based on diurnal flux changes monitored (see below). Continuous measurements were made in irrigation lateral areas where soil water content was the highest throughout the irrigation/growing seasons. Irrigation tubing from DI was removed during measurement and returned afterwards.

\section{Spatial and Diurnal $\mathrm{CO}_{2}$ Emission Measurements}

Spatial and diurnal variation in $\mathrm{CO}_{2}$ emissions surrounding trees during 24 hours was monitored twice during the growing season. The measurement was done every hour except from midnight to dawn (assuming little changes occurring during this time). The first measurements (7-8 May 2014) were made on the irrigation line for all six treatments in one replicate. The second measurements (4-5 June 2014) were made on two trees: one from DI and another from SDI at seven locations surrounding each tree (Fig. 2): between the tree and irrigation line (A), irrigation line (B), from the irrigation line towards center of alleyway at half way (C), center of alleyway between two tree rows (D), 1/4 distance from the tree in a tree row (E), midpoint between two trees within a tree row $(\mathrm{F})$, and midpoint between two trees, but in irrigation line $(\mathrm{G})$.

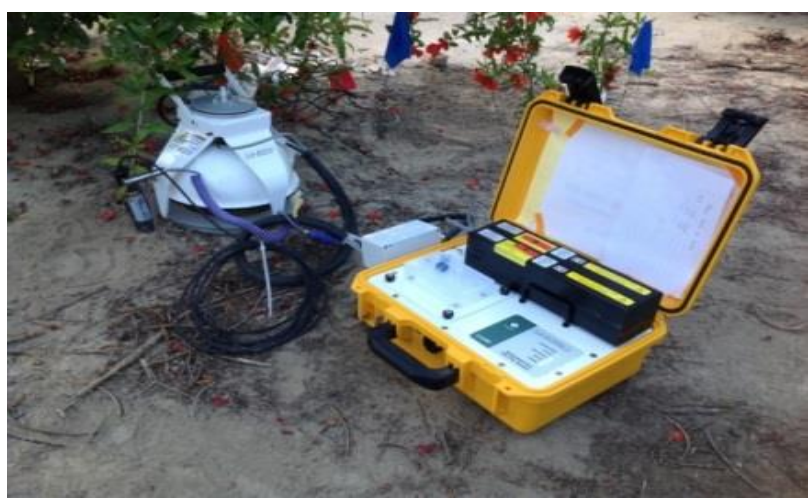

Fig. 1. LI-8100A automated soil $\mathrm{CO}_{2}$ flux system used in this study.

\section{E. Data Processing and Statistical Analysis}

Cumulative $\mathrm{CO}_{2}$ emissions were estimated based on the flux measured during the growing season near drip lines and the spatial and diurnal variation determined surrounding trees from DI and SDI described above. Measured flux between 9:00-11:00 ranging from $87 \%-104 \%$ of average daily rates from 24-hour monitoring. Thus, the measured flux was assumed to represent daily average and used to compute cumulative emissions by integrating with time for area affected by the irrigation. Emissions from other areas surrounding the trees were estimated based on the monitored spatial distribution results. Areas surrounding a tree were divided to different sections to estimate the total emissions from the whole field. Specifically, because large spatial variability was observed for DI, i.e., the highest $\mathrm{CO}_{2}$ flux from irrigation line, lowest from alleyway, and small changes in tree rows, four sections were used to compute cumulative flux: tree line, irrigation line, halfway between irrigation line and midpoint of alleyway, and remainder of the alleyway. For SDI with small variability, two sections were used from tree row toward halfway to the center of alleyway, and the reminder of alleyway. These justifications were made based on the 24-hour flux measurements and believed to give a more reliable estimate for cumulative $\mathrm{CO}_{2}$ emission loss in the orchard.

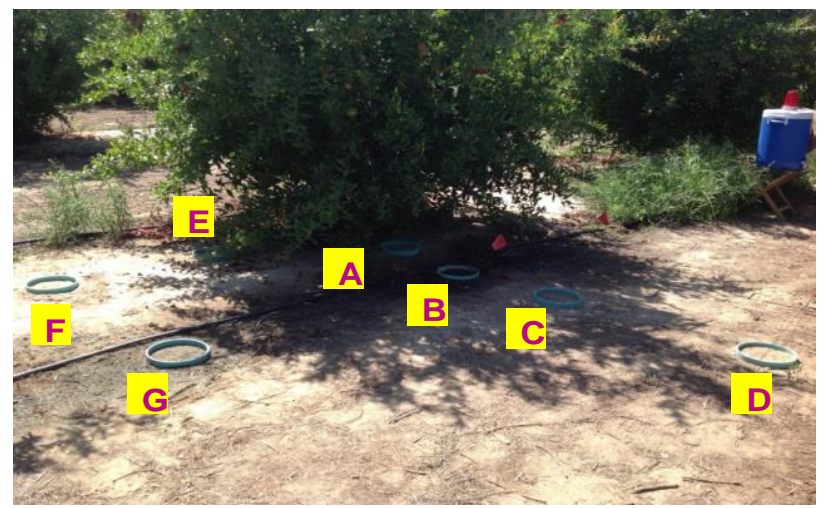

Fig. 2. Monitoring positions around a tree for measuring spatial variation of $\mathrm{CO}_{2}$ flux.

Data on $\mathrm{CO}_{2}$ emission rates, cumulative emissions, and soil DOC were statistically analyzed using $\mathrm{SAS}^{\circledR}$ software 9.4 [30]. For emissions, a split plot mixed model was used with irrigation, $\mathrm{N}$ level, and the interaction as fixed effects. The random effects are block and irrigation $\times$ block. For the emission rate the focus was on the significant irrigation main effect. For cumulative loss, neither irrigation and $\mathrm{N}$ levels main effects were tested significant and an attempt was made on the $\mathrm{N}$ level main effect. For DOC in soil profile, a split plot, repeated measures, mixed model was used. The fixed effects are irrigation, N_level, depth and its interactions with others. The random effects are block, irrigation $\times$ block, and irrigation $\times$ N_level $\times$ block. The latter 3-way interaction defines the experimental units for incorporating a first order, autoregressive covariance structure among the repeated measures in depth. Focus is on the significant irrigation $x$ depth interaction for which means and $95 \%$ confidence intervals were determined.

\section{RESULTS AND DISCUSSION}

\section{A. Soil Moisture and Temperature}

Soil temperature and moisture data monitored for a week in May 2014 are shown in Fig. 3. The DI showed much higher moisture than SDI in surface soils. Gao et al. (2019) [25] reported that soil water content increased as soil depth increased in SDI, but was relatively uniform under DI 
because the high frequency irrigation resulted in surface soil (5 cm depth) near field capacity most of the time. Under SDI, much drier surface soil was monitored with higher water content at deeper depth. The data suggest that drip tubing buried near $50 \mathrm{~cm}$ has limited water movement upward. For DI, the higher surface soil moisture led to higher microbial activity and biomass including weeds [22] that are believed to contribute to the higher $\mathrm{CO}_{2}$ emissions. As for soil temperature, small differences were observed between the irrigation methods (data not shown). The DI showed slightly lower temperature with an ave. $18.49( \pm 3.25){ }^{\circ} \mathrm{C}$ and 19.06 $( \pm 1.53){ }^{\circ} \mathrm{C}$ compared to $20.79( \pm 3.29){ }^{\circ} \mathrm{C}$ and $20.86( \pm 1.49)$ ${ }^{\circ} \mathrm{C}$ at soil depth of $5 \mathrm{~cm}$ and $15 \mathrm{~cm}$, respectively, while air temperature remained the same (ave. $19.03( \pm 6.67)$.

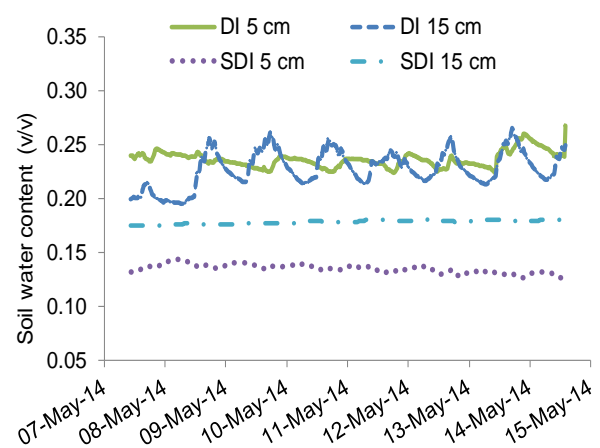

Fig. 3. Continuous soil moisture monitoring under DI and SDI during one week in May 2014. Treatments: DI=surface drip irrigation, SDI=subsurface irrigation. Numerical values are soil depth.

\section{B. $\mathrm{CO}_{2}$ Emission Rates}

Results of the $\mathrm{CO}_{2}$ emission flux during 2014 growing season in the pomegranate orchard are shown in Fig. 4. Consistently higher emission rates near the irrigation line were measured from DI than SDI throughout the growing season at all three $\mathrm{N}$ levels. The average flux values were 2.74, 2.44, and $2.82 \mu \mathrm{mol} \mathrm{m}^{-2} \mathrm{~s}^{-1}$ from DI and 1.91, 1.62, and $1.69 \mu \mathrm{mol} \mathrm{m} \mathrm{m}^{-2} \mathrm{~s}^{-1}$ from SDI, for N1, N2, and N3 treatments, respectively. Statistical analyses showed only irrigation effects was significant, and there were no significant effects of $\mathrm{N}$ level and interaction between irrigation and $\mathrm{N}$ level (Table 2). Estimated average emission rates for DI (2.67 $\left.\mu \mathrm{mol} \mathrm{CO}_{2} \mathrm{~m}^{-2} \mathrm{~s}^{-1}\right)$ were significantly higher than that from SDI $\left(1.74 \mu \mathrm{mol} \mathrm{CO} \mathrm{m}^{-2} \mathrm{~s}^{-1}\right)$.

\section{Spatial Variability of $\mathrm{CO}_{2}$ Emissions}

TABLE II: ANOVA MiXed PROCEDURE TESTS OF THE FIXED EFFECTS ON $\mathrm{CO}_{2}$ EMISSION RATES AND CUMULATIVE EMISSION LOSSES DURING 2014 POMEGRANATE GROWING SEASON

\begin{tabular}{|c|c|c|c|c|}
\hline \multicolumn{5}{|c|}{ Type 3 tests of fixed effects } \\
\hline Effect & Num of DF & Den DF & F Value & $\operatorname{Pr}>F$ \\
\hline \multicolumn{5}{|c|}{$\mathrm{CO}_{2}$ emission rates } \\
\hline Irrigation $\dagger$ & 1 & 10 & 44.64 & $<0.0001$ \\
\hline $\mathrm{N}$ level $\ddagger$ & 2 & 10 & 1.35 & 0.3035 \\
\hline $\begin{array}{l}\text { Irrigation } \times \mathrm{N} \\
\text { level }\end{array}$ & 2 & 10 & 0.48 & 0.6302 \\
\hline \multicolumn{5}{|c|}{$\mathrm{CO}_{2}$ cumulative loss } \\
\hline Irrigation $\dagger$ & 1 & 12 & 0.01 & 0.9072 \\
\hline $\mathrm{N}$ level $!$ & 1 & 12 & 1.65 & 0.2326 \\
\hline $\begin{array}{l}\text { Irrigation } \times \mathrm{N} \\
\text { level }\end{array}$ & 1 & 12 & 0.34 & 0.7196 \\
\hline
\end{tabular}

Spatial variability surrounding a tree in the pomegranate orchard was much larger from DI than SDI (Fig. 5), Under DI, the highest emissions were observed near irrigation line and the lowest was from the center of alleyways while much smaller differences were observed under SDI. The data suggest that both water content and temperature affected $\mathrm{CO}_{2}$ emissions. The diurnal temperature change is shown in Fig. 6. The $\mathrm{CO}_{2}$ emission rate increase correspond to the soil temperature increase (Fig. 6), which explains the diurnal changes. The much higher emission rates from DI than SDI is due to difference in surface soil moisture from irrigation. Peak emission rates under DI is twice those under SDI
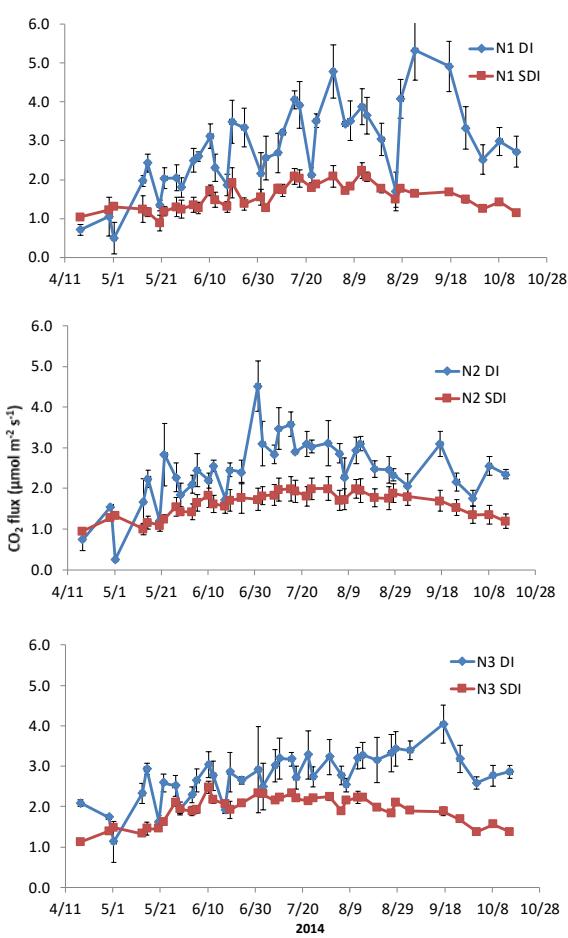

Fig. 4. Carbon dioxide emission flux measured in irrigation line affected area from a pomegranate field during 2014 growing season. Treatments: $\mathrm{DI}=$ surface drip irrigation, $\mathrm{SDI}=$ subsurface irrigation, $\mathrm{N} 1, \mathrm{~N} 2$, and $\mathrm{N} 3=50 \%$, $100 \%$ and $150 \%$ in reference to common practices. Error bars are standard deviations of the mean $(n=3)$.
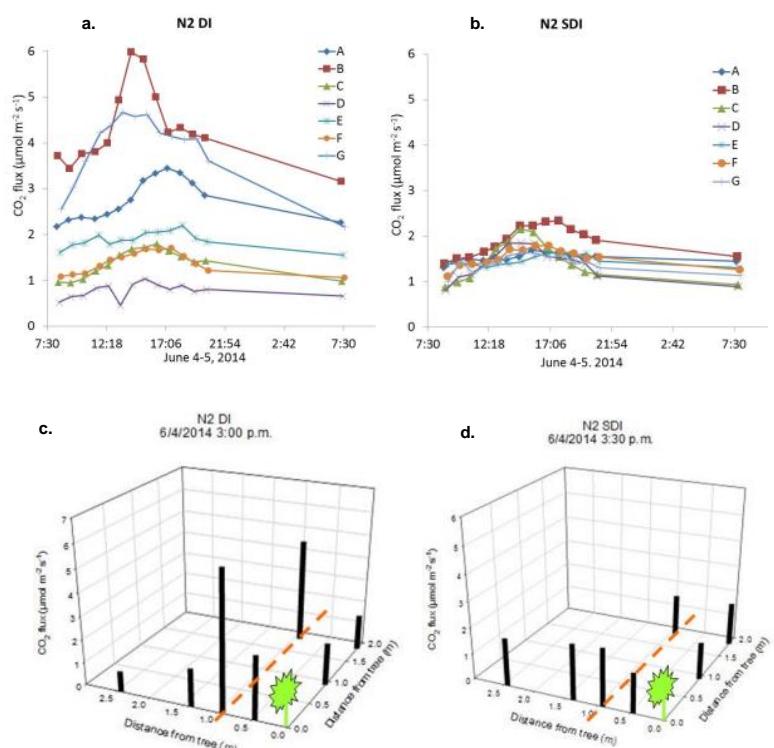

Fig. 5. Carbon dioxide flux measured at various location surrounding a tree from N2 level under DI or SDI. DI and SDI refer to surface drip and subsurface drip irrigation respectively; N2 refers to N application at $100 \%$ level in reference to common practices. 


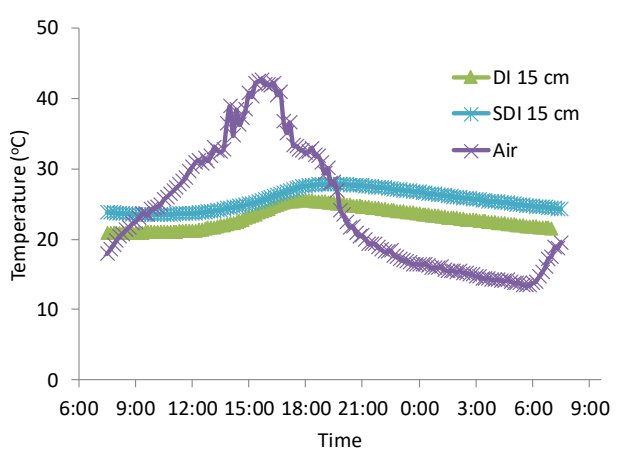

Fig. 6. Soil temperature measured on 4 June 2014 when spatial variability of $\mathrm{CO}_{2}$ emissions was measured.

\section{Cumulative $\mathrm{CO}_{2}$ Emissions}

Cumulative $\mathrm{CO}_{2}$ emissions from the pomegranate orchard during the growing season are shown in Fig. 7. Statistical analysis showed that there were no significant irrigation nor $\mathrm{N}$ treatment effects. This was because although $\mathrm{CO}_{2}$ emission flux can be much higher under DI than SDI near irrigation line, but the wetted area in the orchard accounts for no more than $25 \%$ of the total area. However, measurements for the spatial variability of $\mathrm{CO}_{2}$ emissions were conducted only once, i.e., some errors may be encountered when using the data to justify emission flux for other times. For example, there appears no satisfactory explanation when the center of the alleyway under DI gave much lower $\mathrm{CO}_{2}$ emissions than that under SDI (Fig. 5 c, d). Thus, more evaluations on spatial variability in $\mathrm{CO}_{2}$ emissions are necessary under similar setting that would improve methodology to estimate total emissions from an orchard, especially under DI.

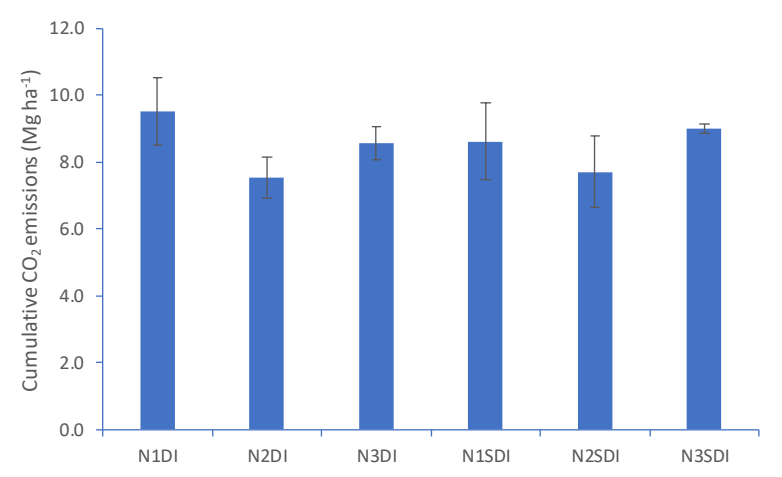

Fig. 7. Cumulative $\mathrm{CO}_{2}$ emission estimates during irrigation season (April-October 2014) in a pomegranate field. DI and SDI refer to surface drip and subsurface drip irrigation respectively; N1, N2, and N3 refer to N application at $50 \%, 100 \%$, and $150 \%$ in reference to common practices. Error bars are standard error of the mean $(n=3)$.

Average cumulative $\mathrm{CO}_{2}$ emissions in our study are 8.54 and $8.44 \mathrm{Mg} \mathrm{ha}^{-1}$ for DI and SDI, respectively. The cumulative emissions in the field from DI appear to be lower than values reported for other types of fields. Guo et al., [20] measured 19.6 $\mathrm{Mg} \mathrm{ha}{ }^{-1} \mathrm{CO}_{2}$ emissions from surface drip irrigated during a summer maze growing season in the North China Plain [20]. The lower $\mathrm{CO}_{2}$ emissions in our study were possibly attributing to tree shading, and large dry surface areas in the field. Guo et al. [20] also found that cumulative $\mathrm{CO}_{2}$ emissions on the irrigation pipes was larger than that between irrigation pipes. Edwards et al. [31] measured emissions from surface and subsurface drip (drip tape buried to $15 \mathrm{~cm}$ soil depth) irrigated tomato field for two years with significantly higher cumulative emissions from surface drip than subsurface drip, but they attributed the difference to sampling time temperature difference and concluded that the irrigation methods did not have a direct impact on $\mathrm{CO}_{2}$ emissions. Fares et al. [32] measured $\mathrm{CO}_{2}$ emissions from different irrigation levels [75\% (deficit), $100 \%$, and $125 \%$ (excess) of reference crop evapotranspiration] using surface drip irrigation system and found no statistical differences among the irrigation levels. Our study had a much deeper subsurface drip irrigation $(\sim 50 \mathrm{~cm}$ depth $)$ that showed restricted water movement to surface (Fig. 3) resulting in significantly lower $\mathrm{CO}_{2}$ emissions near drip lines.

\section{E. Relationship between $\mathrm{CO}_{2}$ Flux and Soil Temperature and Water Content}

A much stronger temperature correlation to $\mathrm{CO}_{2}$ flux was shown under DI than SDI, but there is no clear correlation to soil moisture under either DI or SDI (Fig. 8). This might be because high irrigation frequency maintained the soil condition to be either wet (DI) or dry (SDI) most times temperature effect became dominant (Fig. 8a). The temperature effect was stronger under DI (Deeper slope) than SDI (Fig. 8b).

The observed $\mathrm{CO}_{2}$ flux increase as soil water content increased from DI drip lines was due to enhanced microbial activities. This can be illustrated by the lower $\mathrm{CO}_{2}$ emissions from drier surface soil under SDI compared to those from DI in our study. In a column study, Wei et al. [17] reported subsurface watering resulted in reduced $\mathrm{CO}_{2}$ emissions. Sainju et al. [15] found that irrigation increased $\mathrm{CO}_{2}$ emissions flux by $13 \%$ in compared with non-irrigation in North Dakota, USA. In comparison with different amounts of water irrigation to surface soil, Zornoza et al. [9], [10] showed deficit irrigation, especially with more than one dry period, significantly reduced $\mathrm{CO}_{2}$ emissions in woody orchards in Spain. They found that although microbial biomass did not appear to be affected by deficit irrigation, $\beta$-glucosidase activity was significantly higher under full irrigation and positively correlate with $\mathrm{CO}_{2}$ emissions, suggesting a significant fraction of $\mathrm{CO}_{2}$ emitted from soil derives from degradation of organic matter.
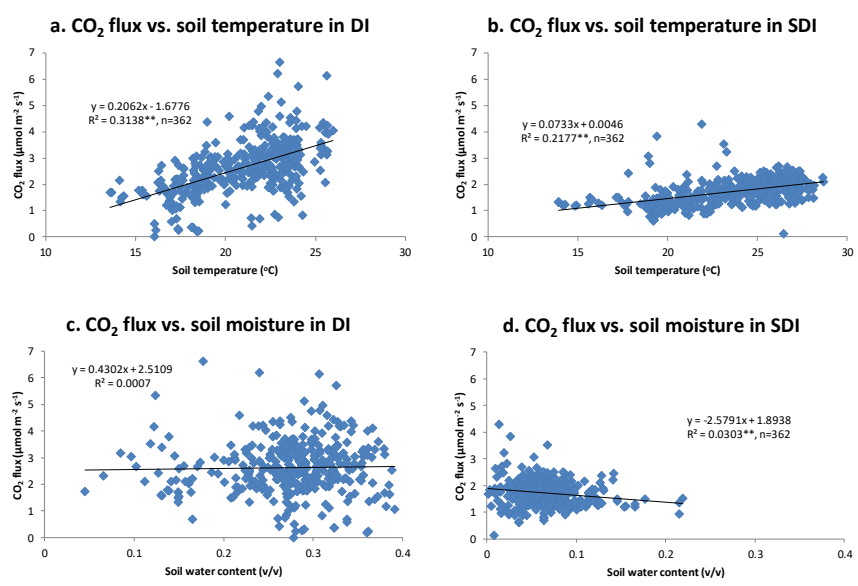

Fig. 8. Correlations between $\mathrm{CO}_{2}$ emission flux and soil temperature or water content during growing season in pomegranate orchard.

\section{F. Soil Dissolved Organic Carbon}

Dissolved organic carbon is defined operationally as the 
organic carbon with small sizes that can pass through a given filter size ( 0.45 micrometers is often used). The DOC includes the breakdown products from dead organic materials that serve as a food or energy source for the growth of microorganisms. Thus, higher DOC represents higher microbial activities or respiration. Statistical analysis showed that DOC in soil by end of pomegranate growing season were significantly affected by depth and interaction with irrigation (Table 3). While there were no significant differences in DOC at most soil depths between the irrigation treatments, DI did show a much higher DOC level than that from SDI in surface $15 \mathrm{~cm}$ soil (Fig. 9). Total soil organic $\mathrm{C}$ decreased as depth increased in both DI and SDI, but at $45 \mathrm{~cm}$ depth or below, SDI began to have slightly higher DOC. This trend agrees with soil total organic carbon (TOC) data that subsurface soil under SDI had similar or higher TOC than DI [24]. The data indicate higher microbial activities in surface soil under DI due to more available energy source, which could be from more dead leaves or weeds than SDI [22]. Although $\mathrm{CO}_{2}$ production in subsurface soil could be high from SDI due to higher water content, it would be subject to a longer pathway before reaching the surface and emit to the atmosphere when chemical dissolution [18] could have occurred resulting in the much lower net emissions under SDI.

Nitrogen application levels did not affect $\mathrm{CO}_{2}$ emission in this study. Both Ayars et al. [22] and Tirado-Corbalá et al. [24] have demonstrated that N3 treatment provided unnecessarily high $\mathrm{N}$ for the pomegranate demand although it resulted in highest TOC in soil. The no significant difference in DOC (Table 3) from the various $\mathrm{N}$ level may suggest that microbial activities were not limited by nutrients and possibly energy source, but more by moisture condition affected by irrigation methods. However, $\mathrm{N}_{2} \mathrm{O}$ emissions were much higher at higher $\mathrm{N}$ application levels (25).

TABLE III: ANOVA MIXED PROCEDURE TESTS OF THE FIXED EFFECTS ON SOIL DOC DATA ANALYSIS BY THE END OF 2014 POMEGRANATE GROWING SEASON

\begin{tabular}{|c|c|c|c|c|}
\hline \multicolumn{5}{|c|}{ Type 3 tests of fixed effects } \\
\hline Effect & Num of DF & Den DF & F Value & $\operatorname{Pr}>\mathrm{F}$ \\
\hline Irrigation $\dagger$ & 1 & 12.1 & 0.10 & $<0.7568$ \\
\hline $\mathrm{N}$ levelt & 2 & 12.1 & 0.28 & 0.7637 \\
\hline Irrigation $\times \mathrm{N}$ level & 2 & 12.1 & 1.27 & 0.3151 \\
\hline Depth§ & 3 & 27.8 & 41.84 & $<0.0001$ \\
\hline Irrigation $\times$ depth & 3 & 27.8 & 3.49 & 0.0289 \\
\hline $\mathrm{N}$ level $\times$ depth & 6 & 29 & 0.65 & 0.6918 \\
\hline Irrig $\times N$ level $\times$ depth & 6 & 29 & 0.28 & 0.9423 \\
\hline
\end{tabular}

$\dagger$ Irrigation treatment: DI, surface drip irrigation; SDI, subsurface irrigation. $\$ \mathrm{~N}$ level treatment: $50 \%, 100 \%$, and $150 \%$ in reference to common practices. $\S$ Soil depth: 0-15, 15-30, 30-45, 45-60 cm.

\section{G. Benefits of Subsurface Drip Irrigation}

While $\mathrm{CO}_{2}$ emission flux generally increased as soil water content increased, the relationship between water content and soil respiration components is not clear. Moinet et al. [33] studied soil respiration in relation to water content and soil organic $\mathrm{C}$ in a grassland ecosystem using ${ }^{13} \mathrm{C}$ technique to partition total soil respiration $\left(\mathrm{R}_{\mathrm{S}}\right)$ into its components soil heterotrophic respiration $\left(\mathrm{R}_{\mathrm{H}}\right)$ and soil autotrophic respiration $\left(R_{A}\right)$. They found that the $R_{H}$ is insensitive to change in soil water content, but is sensitive to organic matter accessible to microbes. $R_{S}$ and $R_{A}$ were strongly correlated and both showed strong linear relationship with gravimetric water content $\left(\mathrm{W}_{\mathrm{S}}\right)$ and soil temperature $\left(\mathrm{T}_{\mathrm{S}}\right)$ as well as DOC. $R_{H}$, however, was not related to variation in $W_{S}$ and $T_{S}$, but was correlated with the amount of soil particulate organic matter, a labile fraction of $\mathrm{C}$. They concluded that microbial accessibility to substrate, rather than chemical structure, is predominant in regulating soil organic matter decomposition. Our data show that DI resulted not only higher surface water content but also high DOC. If the elevated water content from DI increased $R_{A}$ and $R_{S}$, then $R_{H}$ would also increase due to the higher labile organic $\mathrm{C}$ that led to a net increase of $\mathrm{CO}_{2}$ emissions compared to the SDI.

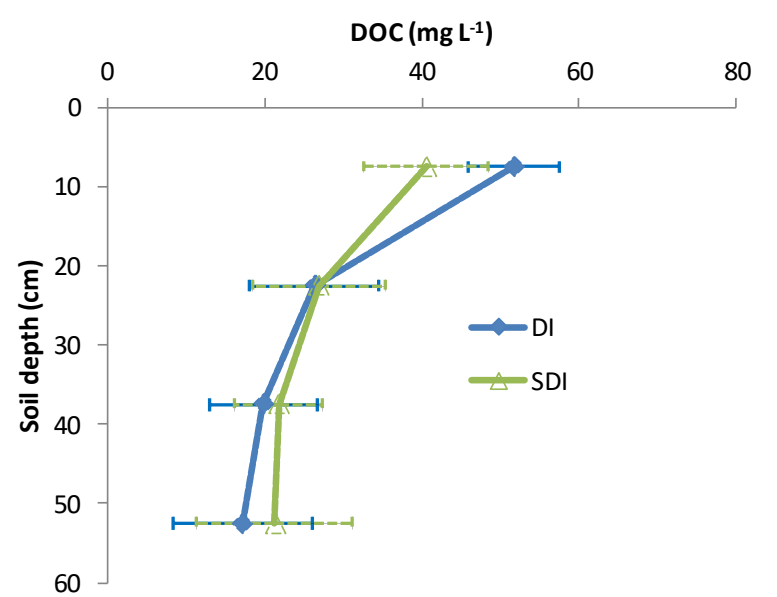

Fig. 9. Dissolved organic carbon (DOC) content in soil (1:1 soil/water ratio) that were collected at the end of growing season in pomegranate orchard. Error bars are $95 \%$ confidence intervals.

Although total $\mathrm{CO}_{2}$ emissions from DI were not significantly higher from SDI in our study, we believe DI leads to generally higher emissions. Subsurface drip irrigation has tendency to yield lower $\mathrm{CO}_{2}$ emissions as other studies have also shown the positive correlation between water content and $\mathrm{CO}_{2}$ emissions [9], [10], [15]. Fewer studies have examined the difference between DI and SDI and evidence from Wei et al. [17] and our studies suggest generally lower greenhouse gas emissions from subsurface irrigation because of reduced $\mathrm{N}_{2} \mathrm{O}$ emissions [25]. The SDI also led to higher water use efficiency and much lower weed pressure Ayars et al. [22] as well as higher $\mathrm{N}$ use efficiency Tirado-Corbalá et al. [24]. Thus, SDI provides generally more benefits than DI in water and nutrient management and mitigating greenhouse gas emissions.

\section{CONCLUSIONS}

Field data collected from an irrigated pomegranate orchard illustrated that DI led to much higher $\mathrm{CO}_{2}$ emission flux at the irrigation line compared to that from SDI with drip tubing installed at about $0.5 \mathrm{~m}$ depth below soil surface. The differences are attributed to soil water content that affect biological activities in surface soil. Although estimated cumulative emissions from the whole orchard were not significantly different due to relatively small wetting areas by drip irrigation, SDI provides more benefits by increasing 
water and nutrient especially $\mathrm{N}$ use efficiency, potentially reducing chemical use because of lower weed populations, and reducing GHG emissions $\left(\mathrm{N}_{2} \mathrm{O}\right.$ and $\left.\mathrm{CO}_{2}\right)$. Thus, SDI is still considered a promising efficient strategy for resource management and improvement on sustainability of crop production.

\section{CONFLICT OF INTEREST}

The authors declare no conflict of interest.

\section{AUTHOR CONTRIBUTIONS}

Dr. Gao led this research and drafted the manuscript. Ms. Hendratna, Dr. Cai, and Dr. Qin assisted data collection and processing. Mr. Pflaum helped data processing and edited the paper. Dr. Phene designed the experiment and maintained field operations.

\section{ACKNOWLEDGMENT}

We would like to express our appreciation for making field measurements by Mr. Robert Shenk and Mr. Mathew Brase, USDA, Agricultural Research Service, San Joaquin Valley Agricultural Sciences Center, Parlier, CA, USA 93648.

\section{REFERENCES}

[1] USEPA. (2019). Overview of greenhouse gases. [Online]. Available: https://www.epa.gov/ghgemissions/overview-greenhouse-gases

[2] B. Bond-Lamberty and A. Thomson, "Temperature-associated increases in the global soil respiration record," Nature, vol. 464, pp. 579-582, 2010.

[3] Food and Agriculture Organization of the United Nations (FAO). (2015). Soils help to combat and adapt to climate change by playing a key role in the carbon cycle. [Online]. Available: http://www.fao.org/3/a-i4737e.pdf

[4] D. G. Kim, A. D. Thomas, D. Pelster, T. S. Rosenstock, and A. Sanz-Cobena, "Greenhouse gas emissions from natural ecosystems and agricultural lands in sub-Saharan Africa: synthesis of available data and suggestions for further research," Biogeosciences, vol. 13, pp. 4789-4809, 2016.

[5] C. Oertel, J. Matschullat, K. Zurba, F. Zimmermann, and S. Erasmi, "Greenhouse gas emissions from soils - A review," Chem. Erde, vol. 76, pp. 327-352, 2016.

[6] K. Paustian, J. Six, E. T. Elliott, and H. W. Hunt, "Management options for reducing $\mathrm{CO}_{2}$ emissions from agricultural soils," Biogeochemistry vol. 48, pp. 147-163, 2000.

[7] M. Rastogi, S. Singh, and H. Pathak, "Emission of carbon dioxide from soil," Current Science, vol. 82, no. 5, pp. 510-517, 2002.

[8] A. M. Silva-Olaya, C. E. P. Cerri, N. L. Scala Jr., C. T. S. Dias, and C. C. Cerri, "Carbon dioxide emissions under different soil tillage systems in mechanically harvested sugar-cane," Environmental Research Letters, vol. 8, 015014, 2013.

[9] R. Zornoza et al., "Efficient irrigation management can contribute to reduce soil $\mathrm{CO}_{2}$ emissions in agriculture," Geoderma, vol. 263, pp. 70-77, 2016

[10] R. Zornoza, J. A. Acosta, M. Gabarrón, M. Gómez-Garrido, V. Sánchez-Navarro, A. Terrero, S. Martínez-Martínez, Á. Faz, and A. Pérez-Pastor, "Greenhouse gas emissions and soil organic matter dynamics in woody crop orchards with different irrigation regimes," Science of The Total Environment, vol. 644, pp. 1429-1438, 2018.

[11] H. Hou, Y. Yang, Z. Han, H. Cai, and Z. Li., "Deficit irrigation effectively reduces soil carbon dioxide emissions from wheat fields in Northwest China," J Sci. Food Agric., vol. 99, no. 12, pp. 5401-5408, 2019.

[12] R. Brumme and F. Beese, "Effects of liming and nitrogen-fertilization on emissions of $\mathrm{CO}_{2}$ and $\mathrm{N}_{2} \mathrm{O}$ from a temperate forest," J. Geophys. Res., vol. 97, pp. 12851-12858, 1992.

[13] W. X. Ding, L. Meng, Y. F. Yin, Z. C. Cai, and X. H. Zheng, " $\mathrm{CO}_{2}$ emission in an intensively cultivated loam as affected by long-term application of organic manure and nitrogen fertilizer," Soil Biology \& Biochemistry, vol. 39, no. 2, pp. 669-679, 2007.
[14] S. F. Smith and K. R. Brye, "Carbon dioxide emissions as affected by alternative long-term irrigation and tillage management practices in the Lower Mississippi River Valley," The Scientific World Journal, pp. 626-632, 2014.

[15] U. M. Sainju, J. D. Jabro, and W. B. Stevens, "Soil carbon dioxide emission and carbon content as affected by irrigation, tillage, cropping system, and nitrogen fertilization," J. Environ. Qual., vol. 37, no. 1, pp. 98-106, 2008

[16] Q. Wei, J. Xu, S. Yang, L. Liao, G. Jin, Y. Li, and F. Hameed, "Subsurface watering resulted in reduced soil $\mathrm{N}_{2} \mathrm{O}$ and $\mathrm{CO}_{2}$ emissions and their global warming potentials than surface watering," Atmos. Environ., vol. 173, pp. 248-255, January 2018.

[17] R. Ruser, H. Flessa, R. Russow, G. Schmidt, F. Buegger, and J. C. Munch, "Emission of $\mathrm{N}_{2} \mathrm{O}, \mathrm{N}_{2}$ and $\mathrm{CO}_{2}$ from soil fertilized with nitrate: effect of compaction, soil moisture and rewetting," Soil Biology and Biochemistry, vol. 38, no. 2, pp. 263-274, February 2006.

[18] J. Ma, Z. Y. Wang, B. A. Stevenson, X. J. Zheng, and Y. Li, “An inorganic $\mathrm{CO}_{2}$ diffusion and dissolution process explains negative $\mathrm{CO}_{2}$ fluxes in saline/alkaline soils," Sci. Rep., vol. 3, pp. 2025, 2013

[19] M. G. Ryan and B. E. Law, "Interpreting, measuring, and modeling soil respiration," Biogeochemistry, vol. 73, pp. 3-27, 2005.

[20] S. Guo, Y. Qi, Q. Peng, Y. Dong, Y. He, Z. Yan, and L. Wang, "Influences of drip and flood irrigation on soil carbon dioxide emission and soil carbon sequestration of maize cropland in the North China Plain," J. Arid Land, vol. 9, no. 2, pp. 222-233, 2017.

[21] S. Buragiené, E. Šarauskis, K. Romaneckas, A. Adamavičienè, Z. Kriaučiūnienè, D. Avižienytė, V. Marozas, and V. Naujokienè, "Relationship between $\mathrm{CO}_{2}$ emissions and soil properties of differently tilled soils," Sci. Total Environ, vol. 662, pp. 786-795, 2019.

[22] J. E. Ayars, C. J. Phene, R. C. Phene, S. Gao, D. Wang, K. R. Day, and D. J. Makus, "Determining pomegranate water and nitrogen requirements with drip irrigation," Agr. Water Manage., vol. 187, pp. 11-23, June 2017.

[23] California Department of Food and Agriculture (CDFA). (2018). Agricultural Statistics Review. [Online]. Available: https://www.cdfa.ca.gov/statistics/PDFs/2017-18AgReport.pdf

[24] R. Tirado-Corbalá, S. Gao, J. E. Ayars, D. Wang, C. J. Phene, and R. C. Phene, "Carbon and nitrogen dynamics affected by different irrigation and fertilization practices in a pomegranate orchard," Horticulturae, vol. 5, no. 4 , p. 77

[25] S. Gao, A. Hendratna, Z. Cai, Y. Duan, R. Qin, and R. Tirado-Corbalá, "Subsurface drip irrigation reduced nitrous oxide emissions in a pomegranate orchard," Int. J. Environ. Sci. Dev., vol. 10, no. 3, pp. $79-85,2019$.

[26] T. H. Skaggs, T. J. Trout, J. Šimůnek, and P. J. Shouse, "Comparison of HYDRUS-2D simulations of drip irrigation with experimental observations," J. Irrig. Drain. Eng., vol. 130, no. 4, pp. 304-310, 2004

[27] L. R. Cohen et al., "Measuring diurnal cycles of evapotranspiration in the Arctic with an automated chamber system," Ecohydrology, vol. 8, no. 4, pp. 652-659, 2014

[28] R. Madsen, L. Xu, B. Claassen, and D. McDermit, "Surface monitoring method for carbon capture and storage projects," Energy Proc, vol. 1, pp. 2161-2168, 2009.

[29] C.-M. Görres, C. Kammann, and R. Ceulemans, "Automation of soil flux chamber measurements: potentials and pitfalls," Biogeosciences, vol. 13, no. 6, pp. 1949-1966, 2016.

[30] The data analysis for this paper was generated using SAS software, Copyright $\odot 2013$ SAS Institute Inc., SAS and all other SAS Institute Inc. product or service names are registered trademarks or trademarks of SAS Institute Inc., Cary, NC, USA.

[31] K. P. Edwards, C. A. Madramootoo, J. K. Whalen, V. I. Adamchuk, A. $\mathrm{S}$. M. Su, and H. Benslim, "Nitrous oxide and carbon dioxide emissions from surface and subsurface drip irrigated tomato fields," Can. J. Soil Sci., vol. 98, no. 3, pp. 389-398, 2018.

[32] A. Fares et al., "Carbon dioxide emission in relation with irrigation and organic amendments from a sweet corn field," J. Environ. Sci. Health, Part B, vol. 52, no. 6, 2017.

[33] G. Y. K. Moinet, E. Cieraad, J. E. Hunt, A. Fraser, M. H. Turnbull, and D. Whitehead, "Soil heterotrophic respiration is insensitive to changes in soil water content but related to microbial access to organic matter," Geoderma, vol. 274, pp. 68-78, 2016.

Copyright $\odot 2020$ by the authors. This is an open access article distributed under the Creative Commons Attribution License which permits unrestricted use, distribution, and reproduction in any medium, provided the original

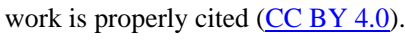




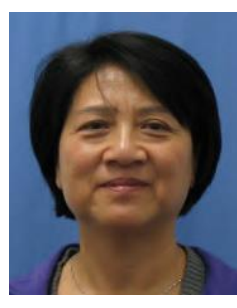

Suduan Gao is a research soil scientist in USDA, ARS, SJVASC, Water Management Research Unit, located at Parlier, CA, USA. She received her MS degree in Chinese Academy of Agricultural Sciencies in 1985 and Ph.D in soil science from Universitiy of California Davis (UC Davis) in 1992. Following her $\mathrm{Ph} . \mathrm{D}$, she conducted 12 years of environmental research in UC Davis as a postodoc and an independent researcher. In 2004, Dr. Gao joined USDA-ARS and has been conducting research on the fate of agronomic chemicals, improve their use efficiency, and reduce environmental impact.

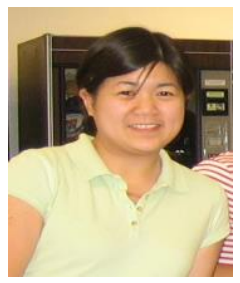

Aileen Hendratna received her MS degree in water system technology from Royal Institute of Technology, Stockholm, Sweden in 2011 and BS degree in soil and water science from University of California Davis in 2004. She is a Biological Science Technician in USDA, ARS, SJVASC, Water Management Research Unit located at Parlier, CA, USA.

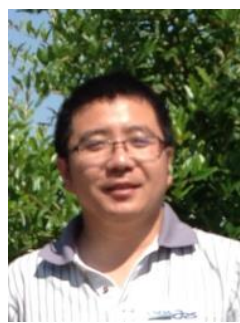

Zejiang Cai received his MS degree in soil science from Graduate School of Chinese Academy of Agricultural Sciences (CAAS), China. He is assistant professor in Hengyang Red Soil Experimental Station of CAAS, Qiyang, Hunan province, China. He is studying the effectiveness and mechanisms of animal manures and crop straws to develop effective strategies to ameliorate soil acidity and conducted research on $\mathrm{N}_{2} \mathrm{O}$ emission and $\mathrm{N}$ transformation dynamics in soil.

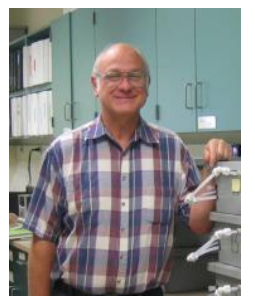

Tom Pflaum received his MS degree in chemistry from California State University, Fresno in 1979 and BS degree in chemistry from California State University, Fresno in 1975.

His current position is specialist/chemist emeritus with the USDA, ARS, SJVASC, Water Management Research Unit, located at Parlier CA, USA starting in 2011. Previously, he was an analytical chemist /support scientist at Water Management Research Unit from 1987 to his early retirement in 2011. He was employed as Director of Quality Control/Analytical Chemist in a pharmaceutical Manufacturing firm from 1979 to 1987

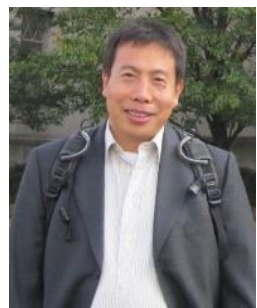

Ruijun (Ray) Qin is an assistant professor and agronomist at Oregon State University. He received his MS degree in soil science from Chinese Academy of Agricultural Sciences in 1995 and $\mathrm{Ph} . \mathrm{D}$. in agronomy from Swiss Federal Institute of Technology Zurich (ETHZ), Switzerland in 2003 $\mathrm{He}$ develops extension and research program focusing on field crop agronomy and soil / nutrient / water management of high value irrigated crops in north-central and north-eastern Oregon and south-central Washington, exploring environmentally sustainable and crop-effective strategies.

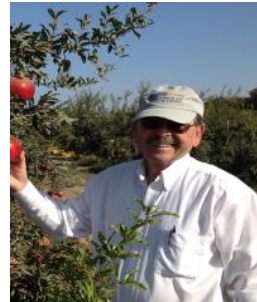

Claude J. Phene received his BA in Physics (1966) and Ph.D. in Soil Physics (1970) both from the University of California, Riverside, CA. He was the former research leader at the USDA, ARS, WMRL Water Management Research Laboratory located in Fresno, CA, USA. Following 26.5 years of research, he retired in January 1994. Since then, he has consulted worldwide in irrigation and soil physics. 